\title{
LCE3B wt Allele
}

National Cancer Institute

\section{Source}

National Cancer Institute. LCE3B wt Allele. NCI Thesaurus. Code C131198.

Human LCE3B wild-type allele is located in the vicinity of $1 \mathrm{q} 21.3$ and is approximately $1 \mathrm{~kb}$ in length. This allele, which encodes late cornified envelope protein 3B, plays a role in the keratinization of the epidermis. Variation of the gene may be associated with psoriatic arthritis. 